\title{
Изменчивость водного режима рек донского бассейна
}

\author{
М. А. Чернова ${ }^{1}$ 府, С. Н. Дудник ${ }^{2}$, М. Е. Буковский ${ }^{1}$ \\ ${ }^{1}$ Тамбовский государственный университет им. Г.Р. Державина, Российская Федерация \\ (392036, г. Тамбов, ул. Интернациональная, 33) \\ ${ }^{2}$ Тамбовский иентр по гидрометеорологии и мониторингу окружающей среды - филиал \\ Федерального государственного бюджетного учреждения «Центрально-Черноземное управление по \\ гидрометеорологии и мониторингу окружающей среды», Российская Федерация \\ (392008, г. Тамбов, ул. Советская, 182)
}

\begin{abstract}
Аннотация: В статье рассматривается изменение водного режима рек, относящихся к бассейну Дона в пределах территории Тамбовской области. Параметры водного режима рассматриваются в течение трех периодов: 1956-1976 гг., 1977-1997 гг., 1998-2018 гг. Работа выполнена в сотрудничестве с Тамбовским центром по гидрометеорологии и мониторингу окружающей среды.

Цель: проанализировать изменения водного режима рек донского бассейна на территории Тамбовской области за период с 1956 года по 2018 год.

Meтоды: аналитический подход к обработке информации. Оцифровка необходимых для проведения исследований данных из журналов гидрологических наблюдений.

Pезультаты: показано, что доля весеннего половодья в общем объеме годового стока постепенно сокращается от 50-х годов XX века к современному периоду, число случаев наступления высоких уровней весеннего половодья снижается в современный период, а продолжительность половодья на изученных реках несколько увеличивается. Считается, что питание рек донского бассейна преимущественно снеговое. За счет интенсивного снеготаяния и происходит формирование максимального стока в период весеннего половодья. Иногда на характер питания рек Тамбовской области накладываются продолжительные дождевые осадки, формирующие летне-осенний паводок.

Bblводbl: согласно результатам, полученным в ходе настоящего исследования, можно сказать, что в ряде случаев вопрос о типе питания изученных рек становится дискуссионным. Также установлено, что даты максимальных уровней половодья постепенно смещаются на более позднее время. По результатам проведенного исследования составлены карты-схемы, отражающие долю стока за период половодья, по отношению к годовому стоку на реках Тамбовской области, принадлежащих донскому бассейну.

Ключевые слова: весеннее половодье, водные ресурсы, гидрологическая изученность, гидрологический режим, донской бассейн, Тамбовская область, сток, межень, расход воды, реки, уровень воды.

Для цитирования: Чернова М.А., Дудник С. Н., Буковский М.Е. Изменчивость водного режима рек донского бассейна // Вестник Воронежского государственного университета. Серия География. Геоэкология, 2020, № 3, c. 40-48. DOI: https://doi.org/10.17308/geo.2020.3/3022
\end{abstract}

\section{ВВЕДЕНИЕ}

На территории Тамбовской области реки имеют широкое эксплуатационное значение. Они отличаются неравномерным характером стока в течение года, высокое весеннее половодье, низкой летней и зимней меженью и слегка повышенным стоком в осенний период. Информация о гидрологическом режиме рек играет важную роль при строительстве мостов, плотин, безопасном пропуске весеннего половодья. Информация о поверхностном стоке важна для сельских, лесных, рыбных хозяйств, организации мест отдыха, спортивного туризма [5].

\section{ИЗУЧЕННОСТЬ ПРОБЛЕМЫ}

Тамбовская область является преимущественно аграрным регионом. Увеличение нагрузки на

() Чернова М. А., Дудник С.Н., Буковский М.Е., 2020

Чернова Мария Александровна, e-mail: chernovamarusya@mail.ru

Контент доступен под лицензией Creative Commons Attribution 4.0 License. 


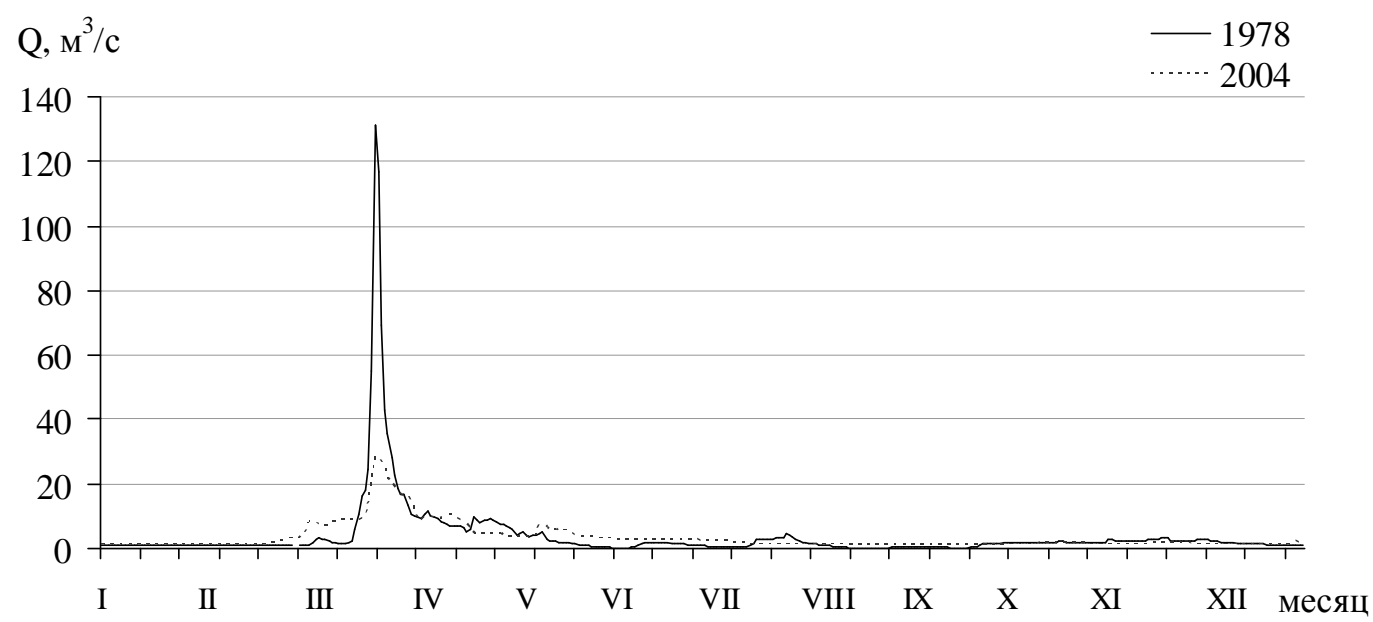

Рuc. 1. Гидрографы р. Битюг - пгт. Мордово

[Fig. 1. Hydrographs of the Bityug River - urban village Mordovo]

поверхностные водные объекты в последние годы практически полностью связано с увеличением посевных площадей и вводом в строй крупных животноводческих предприятий.

Проведенная осушительная мелиорация 70-х80-х годов ХХ века, массовое строительство прудов в верховьях рек, изменения, произошедшие за последние 50 лет в режиме использования водных объектов и прилегающих территорий, привели к изменениям условий формирования стока, а в отдельных случаях, к изменению гидрографической сети, особенно в верховьях рек. Кроме того, в последнее время в связи с нарастающими климатическими изменениями все более ощутимо меняется гидрологический режим рек региона и распределение стока по сезонам года, что влечет за собой необходимость сплошного изучения гидрологических характеристик рек региона.

Гидрографическая сеть Тамбовской области широко представлена реками, болотами, озерами, прудами и водохранилищами. Реки области принадлежат бассейнам двух основных рек - Волги и Дона. Н.И. Дудник отмечал в своих работах, что на территории области насчитывается около 1400 речек. Из них 1200 - имеют длину менее 10 км. Больших рек нет, есть только малые и средние [4]. Наиболее крупными реками Тамбовской области в бассейне Дона являются Ворона, Лесной Воронеж, Польной Воронеж, Матыра, Битюг.

Осадки и температура воздуха непосредственно влияют на пик половодья, его максимальный и минимальный расход, а также определяют его продолжительность и интенсивность [3]. Половодье рек донского бассейна на территории Тамбовской области образуется, в основном, за счет питания реки талыми снеговыми водами.

\section{МЕТОДЫ И МАТЕРИАЛЫ}

На территории Тамбовской области находятся всего 12 гидропостов. В основу настоящей работы положены данные пяти постов, расположенных на реках донского бассейна: река Битюг - гидропост «Мордово»; река Ворона - гидропосты «Чутановка» и «Уварово»; река Мокрая Панда - гидропост «Курдюки»; река Лесной Воронеж - гидропост «Заворонежское».

Работа велась в тесном сотрудничестве с Тамбовским центром по гидрометеорологии и мониторингу окружающей среды - филиалом ФГУ «Центрально-Черноземное УГМС».

В статье обработаны и проанализированы первичные данные гидрологических журналов ежедневных уровней и расходов воды за период с 1956 года по 2018 год.

Информация, содержащаяся в гидрологических журналах, была оцифрована авторами в электронные таблицы. Всего было оцифровано около 25550 значений.

Основываясь на полученных данных, определили гидрологические периоды для каждого изучаемого гидропоста: максимальный расход за год и дату его наступления; максимальный расход половодья и дату его наступления; максимальный уровень половодья и дату его наступления; продолжительность половодья.

Для рек, расположенных в пределах Тамбовской области, впервые за 60 лет были актуализированы описания гидрологического режима рек и проанализирована динамика стока воды более чем за шестидесятилетний период. В результате было установлено изменение внутригодового распределения стока поверхностных водотоков по сравне- 

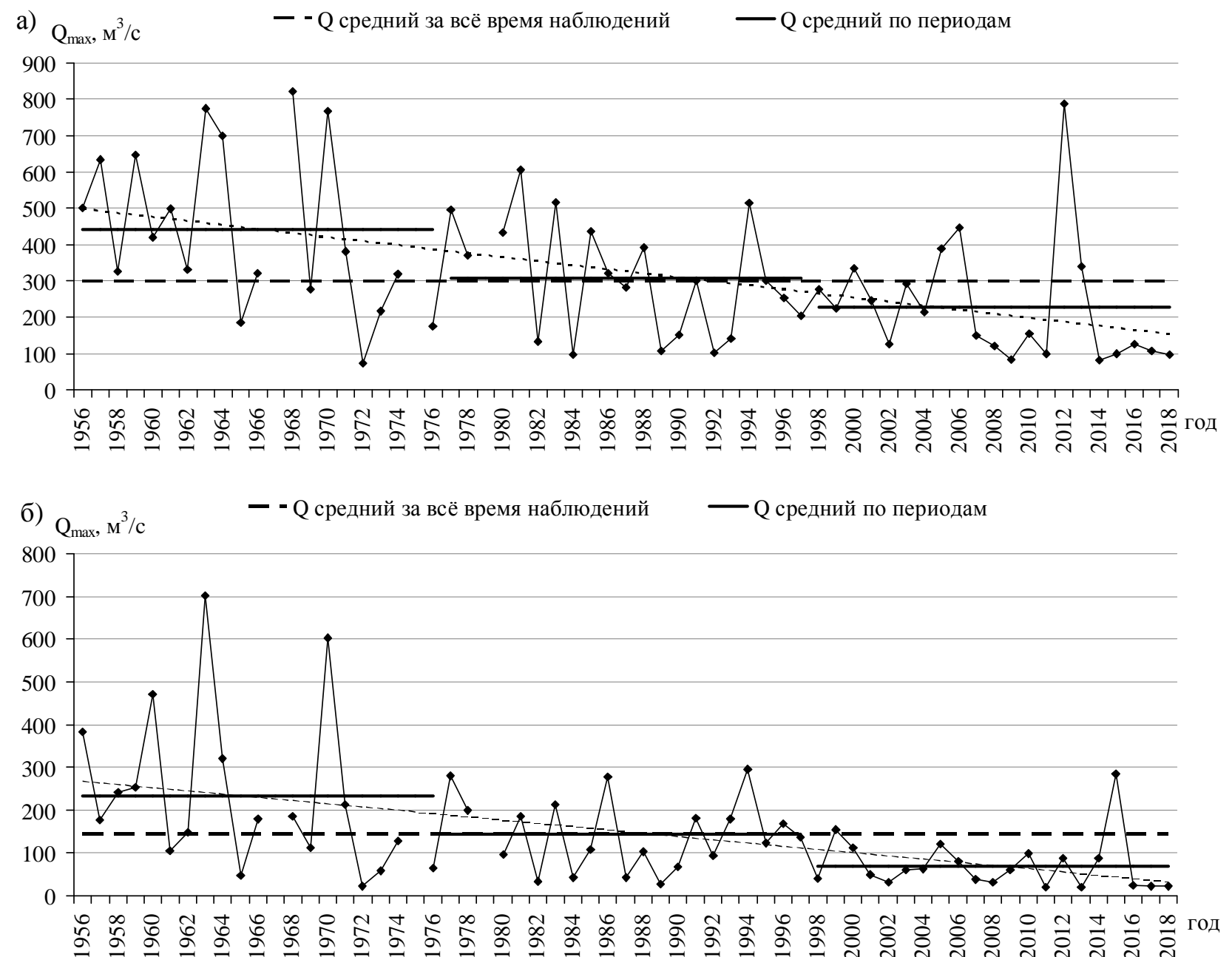

Рuc. 2. Максимальные расходы воды весеннего половодья:

а) р. Ворона - г. Уварово за период с 1956 по 2018 гг;

б) р. Лесной Воронеж - с. Заворонежское за период с 1956 по 2018 гг.

[Fig. 2. Fig. 2. Maximum flow of spring flood water:

a) the Vorona River - the city of Uvarovo for the period from 1956 to 2018;

b) the Lesnoy Voronezh River - village Zavoronezhskoe for the period from 1956 to 2018]

нию с оценкой, проводившейся в 70-х годах прошлого века.

Данные анализировались по трем периодам: 1956-1976 гг., 1977-1997 гг., 1998-2018 гг. Выбор начального года первого периода объясняется наличием данных на одном из вышеперечисленных гидропостов именно с 1956 года, а в 1973 году вышел в свет том «Ресурсов поверхностных вод $\mathrm{CCCP}$ » о реках донского бассейна [5]. Так же с середины 70-х годов на территории Тамбовской области проводилась масштабная гидромелиорация. Второй период является промежуточным, благодаря которому можно отследить изменения во времени по сравнению с первым периодом. Третий период соответствует современному времени и отражает ситуацию на данный момент. Все периоды аналогичны по количеству лет.

\section{РЕЗУЛЬТАТЫ И ОБСУЖДЕНИЕ}

Максимальные суточные расходы в первом периоде чаще наблюдаются в конце 60-х - начале 70-х годов. Во втором периоде почти все регистрируемые суточные максимумы расходов вод наблюдались в 1981 году. В оставшемся третьем периоде с 1998 года по 2018 год распределение максимальных расходов неоднородно.

Рисунок 1 отражает типичные гидрографы, характерные для рек донского бассейна. В качестве примера приведены наиболее типичные для многоводного (1978 г.) и маловодного (2004 г.) годов гидрографы реки Битюг (гидропост Мордово). Установлено, что на Дону половодье может идти довольно продолжительное время. Характерный гидрограф рек донского бассейна территории 
Наступление максимальных экстремумов весеннего половодья на реках донского бассейна, декада/месяц

[Table. The beginning of the maximum spring flood on the rivers of the Don basin, decade/month]

\begin{tabular}{|c|c|c|c|c|c|c|}
\hline \multirow[b]{2}{*}{$\begin{array}{c}\text { Река - } \\
\text { гидропост } \\
\text { [River - } \\
\text { hydrological } \\
\text { post] }\end{array}$} & \multicolumn{2}{|c|}{ 1956-1976 } & \multicolumn{2}{|c|}{$1977-1997$} & \multicolumn{2}{|c|}{ 1998-2018 } \\
\hline & 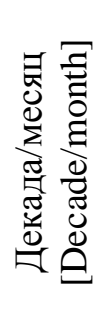 & 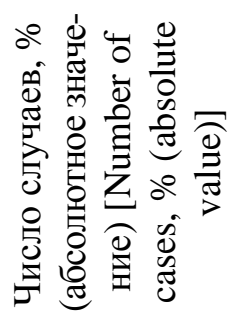 & 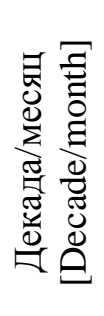 & 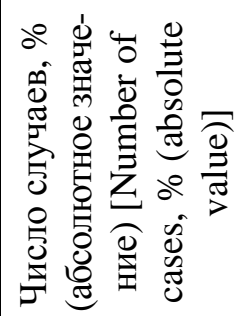 & 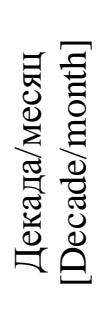 & 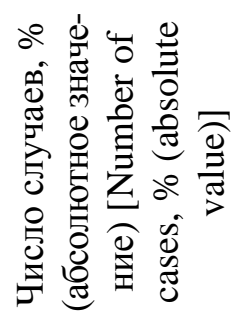 \\
\hline \multirow{3}{*}{$\begin{array}{l}\text { Битюг - } \\
\text { р.п. } \\
\text { Мордово } \\
\text { [Bityug - } \\
\text { Mordovo] }\end{array}$} & III/3 & $24(5)$ & \multirow[b]{3}{*}{$\mathrm{I} / 4$} & \multirow[b]{3}{*}{$48(10)$} & \multirow[b]{3}{*}{$\mathrm{I} / 4$} & \multirow[b]{3}{*}{$52(11)$} \\
\hline & $\mathrm{I} / 4$ & $24(5)$ & & & & \\
\hline & $\mathrm{II} / 4$ & $24(5)$ & & & & \\
\hline $\begin{array}{l}\text { Ворона - } \\
\text { г. Уварово } \\
\text { [Vorona - } \\
\text { Uvarovo] }\end{array}$ & $\mathrm{II} / 4$ & $43(9)$ & $\mathrm{II} / 4$ & $52(11)$ & II/4 & $38(8)$ \\
\hline $\begin{array}{l}\text { Ворона - } \\
\text { с. Чутанов- } \\
\text { ка [Vorona } \\
\text { - Chutanov- } \\
\text { ka] }\end{array}$ & $\mathrm{I} / 4$ & $43(9)$ & $\mathrm{II} / 4$ & $52(11)$ & $\mathrm{II} / 4$ & $43(9)$ \\
\hline $\begin{array}{l}\text { Мокрая } \\
\text { Панда - } \\
\text { д. Курдюки } \\
\text { [Mokraya } \\
\text { Panda - } \\
\text { Kurdyuky] }\end{array}$ & $\mathrm{I} / 4$ & $33(7)$ & III/3 & $43(9)$ & $\mathrm{I} / 4$ & $38(8)$ \\
\hline \multirow{2}{*}{$\begin{array}{l}\text { Лесной } \\
\text { Воронеж - } \\
\text { с. Заворо- } \\
\text { нежское } \\
\text { [Lesnoy } \\
\text { Voronezh - } \\
\text { Zavoronezh- } \\
\text { skoe] }\end{array}$} & $\mathrm{I} / 4$ & $29(6)$ & \multirow[b]{2}{*}{$\mathrm{I} / 4$} & \multirow[b]{2}{*}{$43(9)$} & \multirow[b]{2}{*}{$\mathrm{II} / 4$} & \multirow[b]{2}{*}{$33(7)$} \\
\hline & II/4 & $29(6)$ & & & & \\
\hline
\end{tabular}

Тамбовской области имеет обычно одновершинный вид.

Многолетние изменения стока являются отражением последствий изменения климата. Наиболее четкое представление о временной изменчивости максимального стока дают графики многолетних колебаний максимальной за половодье водности рек Ворона у города Уварово и Лесной Воронеж у села Заворонежское за период с 1956 года по 2018 год (рис. 2).

Значения максимального расхода воды рек донского бассейна на территории Тамбовской облас- ти имеют тенденцию к снижению. Реки донского бассейна на территории Тамбовской области расположены в схожих природных условиях, однако даты установления снежного покрова, условия его залегания, типичность половодья и доля половодья в годовом объеме стока для них различаются.

В настоящее время существует предположение о календарном смещении наступления максимальных уровней весеннего половодья на реках донского бассейна. В таблице приведены данные о максимальных экстремумах весеннего половодья на реках донского бассейна в пределах территории 


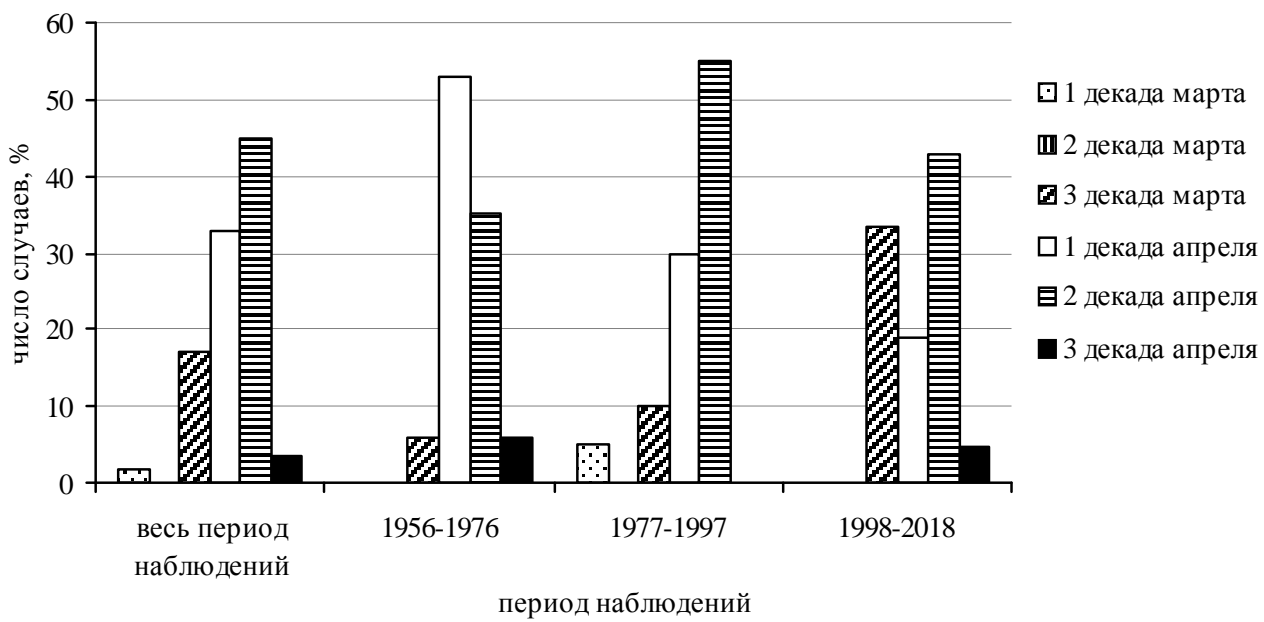

Рuc. 3. Распределение дат наступления по декадам максимальных уровней половодья в p. Ворона у с. Чутановка с 1956 года по настоящее время

[Fig. 3. Distribution of dates of onset by decade of maximum flood levels in the Vorona River near the village of Chutanovka from 1956 to the present]

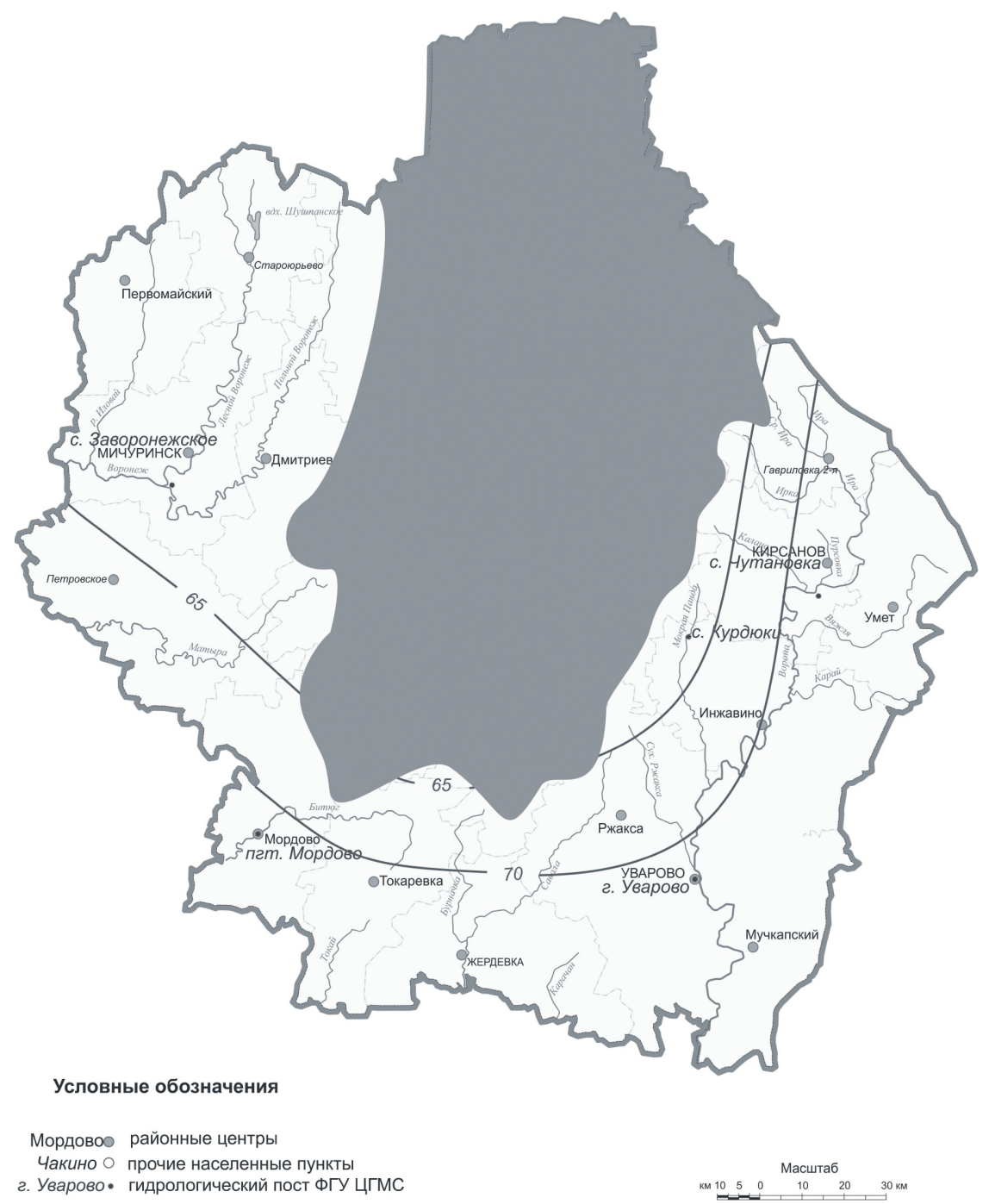

Puc. 4. Доля весеннего стока в годовом объеме (\%) за период с 1956 по 1976 год [Fig. 4. The share of spring runoff in annual total (\%) in the period from 1956 to 1976] 


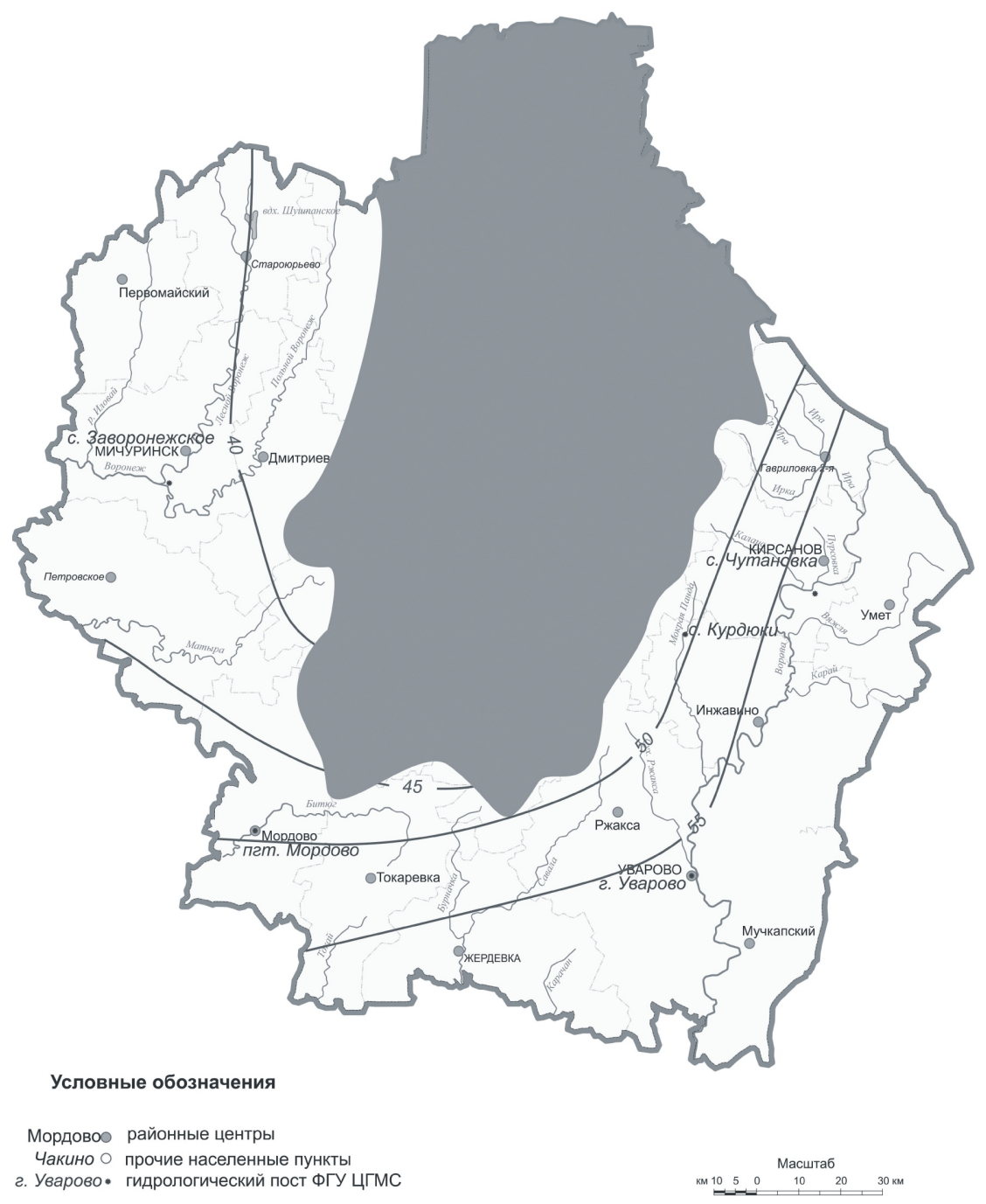

Puc. 5. Доля весеннего стока в годовом объеме (\%) за период с 1977 по 1997 год

[Fig. 5. The share of spring runoff in annual total (\%) in the period from 1977 to 1997]

Тамбовской области для трех изучаемых нами периодах.

Нами, в отличие от коллег, проводивших исследование в более южном регионе, не отмечено статистически достоверного смещения весеннего половодья по датам.

За изучаемые нами три периода соотношение максимальных уровней половодья по декадам распределилось следующим образом, отраженным на рисунке 3 (на примере реки Вороны у села Чутановка).

Если в период с 1956 по 1976 год, дата наступления максимального уровня половодья приходилась, в большинстве случаев, на первую декаду апреля, то уже в следующие 20 лет этот период смещается на вторую декаду апреля. В современный период с 1998 по 2018 год наблюдается увеличение количества случаев фиксации максиму- мов половодья в третьей декаде марта, однако сохраняется преобладание максимальных уровней половодья во второй декаде апреля.

Продолжительность половодья возросла с самого быстротечного периода в 37 суток 1983 года, до самого продолжительного периода в 80 дней, имевшем место в 2004 году. В 2016 году на реках донского бассейна Тамбовской области произошел сильный скачок уровня воды в мае-июне за счет наложившегося мощного дождевого паводка.

Рамки наступления половодья влияют на определение доли стока весеннего половодья. На данный момент доказано, что доля стока за время половодья существенно снижается за счет увеличения доли летней и зимней меженей почти вдвое [5], что является актуальным в современный промежуток времени. Так доля стока зимней межени увеличилась на настоящий момент на $56 \%$ от пер- 


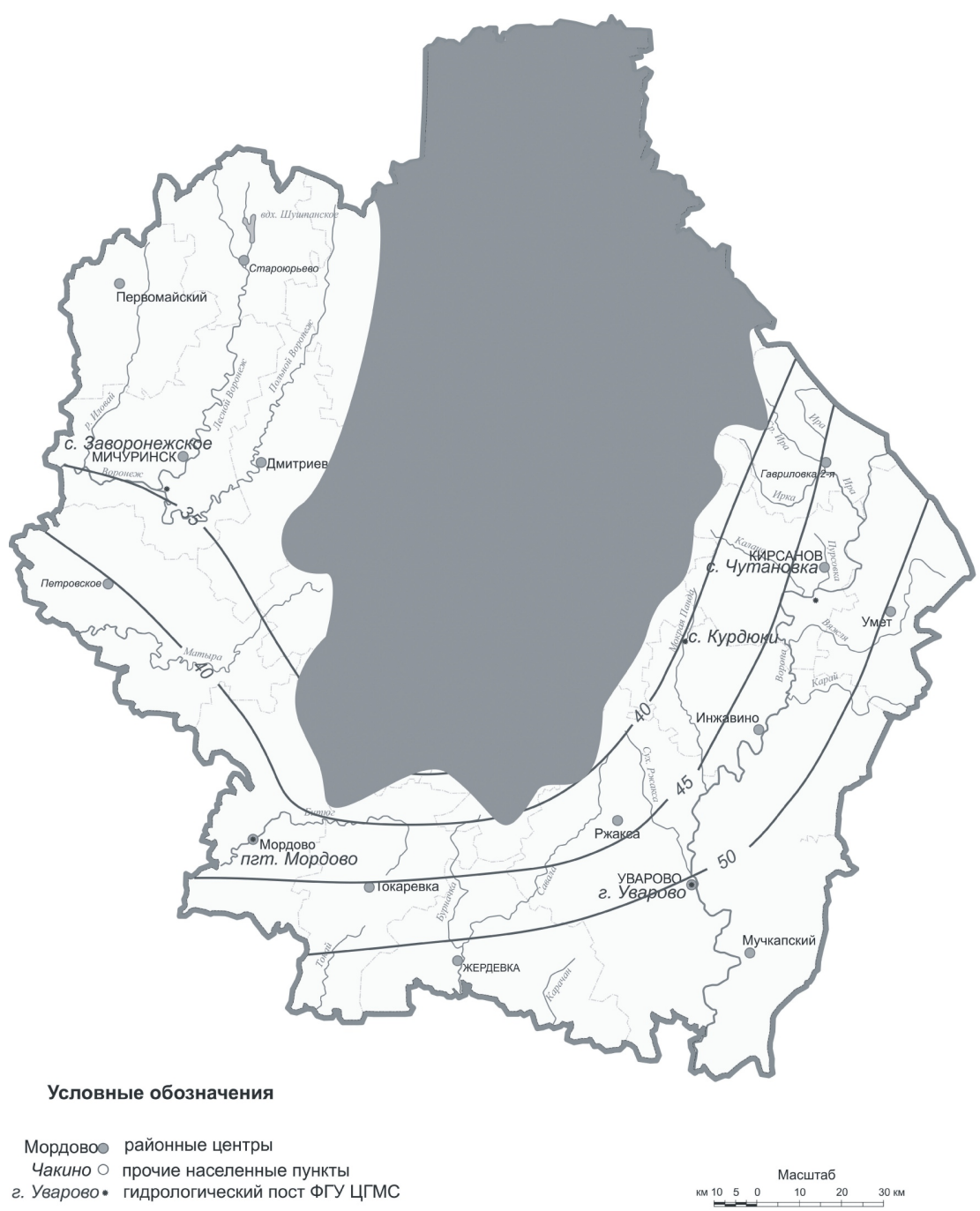

Puc. 6. Доля весеннего стока в годовом объеме (\%) за период с 1998 по 2018 год [Fig. 6. The share of spring runoff in annual total (\%) in the period from 1998 to 1918]

вого периода с 1956 по 1976 год; летнего - на $52 \%$. Доля объема стока половодья колеблется от $73 \%$ в период с 1956 по 1976 год на реке Ворона (с. Чутановка) до 35\%, в период с 1998 по 2018 год на реке Лесной Воронеж (с. Заворонежское).

На рисунках 4, 5 и 6 изображены карты-схемы с изолиниями, отражающими распределение долей весеннего стока в процентном соотношении за три рассматриваемых периода: рисунок 4 - с 1956 по 1976 год, рисунок 5 - с 1977 по 1997 год, рисунок 6 - с 1998 по 2018 год.

Сравнивая рисунки 4 и 5, мы можем заметить сокращение доли весеннего половодья с первого периода 1956-1976 годы (объем стока в годовом объеме 65\%-73\%) до второго периода 1977-1997 (объем стока в годовом объеме 40\%-55\%).

Доля весеннего стока в годовом объеме стока в современном периоде также продолжает сни- жаться. Сейчас доля объема стока за период половодья в общем объеме годового стока колеблется от $35 \%$ до $50 \%$ (рис. 6 ).

\section{ЗАКЛЮЧЕНИЕ}

При сформировавшихся нынешних климатических условиях выделились характерные особенности водного режима рек донского бассейна на территории Тамбовской области. Так доля весеннего половодья в годовом объеме стока уменьшилась в ряде случаев до $35 \%$. Продолжительность половодья несколько увеличивается; смещение дат максимальных уровней половодья наглядно показано произошло в сравнении двух периодов - более раннего 1956-1976 годов (с первой декады апреля) и современного 1998-2018 годов (на вторую декаду апреля), что объясняется изменением климатических условий. 


\section{СПИСОК ЛИТЕРАТУРЫ}

1. Буковский М.Е., Чернова М.А. Оценка изменения летнего стока рек донского бассейна на территории Тамбовской области за последние полвека // Tpyды 9-й Междунар. науч.-практ. конф. «Экология речных бассейнов». Владимир, 2018, с. 33-39.

2. Владимиров А.М. Факторы, определяющие возникновение экстремальных расходов и уровней воды половодья // Ученые записки РГГМУ, 2009, № 9, с. 22-39.

3. Дмитриева В.А. Гидрологический режим рек донского бассейна // Вестник Воронежского государ- ственного университета. Серия: География. Геоэкология, 2018, № 4, с. 77-84.

4. Дудник Н. И. Природа Тамбовского края (nоnулярные географические очерки). Тамбов, изд-во ТГУ им. Г.Р. Державина, 2000. 156 с.

5. Ресурсы поверхностных вод СССР: Гидрологическая изученность. Т. 7. Донской район. Л., Гидрометеоиздат, 1973. 460 с.

Конфликт интересов: Авторы декларируют отсутствие явных и потенциальных конфликтов интересов, связанных с публикацией настоящей статьи.

Поступила в редакцию 04.03.2020

Принята к публикации: 26.07.2020

UDC 556.535

ISSN 1609-0683

DOI: https://doi.org/10.17308/geo.2020.3/3022

\title{
Variability of the Water Regime in the Don Basin Rivers
}

\author{
M. A. Chernova ${ }^{1}$, S. N. Dudnik ${ }^{2}$, M. E. Bukovsky ${ }^{1}$ \\ ${ }^{I}$ Tambov State University named after G. R. Derzhavin, Russian Federation \\ (33, Internacionalnaya st., Tambov, 392036) \\ ${ }^{2}$ Tambov center for hydrometeorology and environmental monitoring - a branch of the Federal state \\ budgetary institution "Central Chernozem administration for hydrometeorology and environmental \\ monitoring”, Russian Federation \\ (182, Sovetskaya st., Tambov, 392008)
}

\begin{abstract}
The article deals with changes in the water regime of rivers belonging to the don basin within the territory of the Tambov region. Water regime parameters are considered during three periods: 1956-1976, 1977-1997, and 1998-2018. The work was carried out in cooperation with the Tambov center for Hydrometeorology and environmental monitoring.

The purpose is to analyze changes in the water regime of the rivers of the Don basin in the Tambov region for the period from 1956 to 2018.

Methods: analytical approach to information processing. Digitization of data required for research from hydrological observation logs.

Results: It is shown that the share of spring flooding in the total annual flow gradually decreases from the 50s of the XX century to the modern period, the number of cases of high levels of spring flooding decreases in the modern period, and the duration of high water on the studied rivers increases slightly. It is believed that the food of the rivers of the don basin is mainly snow. Due to intensive snow melting and the formation of the maximum runoff during the spring flood. Sometimes the nature of the supply of rivers in the Tambov region is superimposed by prolonged rainfall, forming a summer-autumn flood.

Conclusions: According to the results obtained in the course of this study, we can say that in some cases the question of the type of nutrition of the studied rivers becomes debatable. It is also found that the dates of maximum flood levels gradually shift to a later time. Based on the results of the study, maps and diagrams were compiled that reflect the share of runoff during the flood period, in relation to the annual flow on the rivers of the Tambov region belonging to the don basin.
\end{abstract}

Key words: spring flood, water resources, hydrological study, hydrological regime, Don basin, Tambov region, runoff, low water level, water flow, rivers, water level.

(C) Chernova M.A., Dudnik S.N., Bukovsky M.E., 2020

Maria A. Chernova, e-mail: chernovamarusya@mail.ru

(c) (i) The content is available under Creative Commons Attribution 4.0 License.

Вестник ВГУ, Серия: География. Геоэкология, 2020, № 3, 40-48 
For citation: Chernova M. A., Dudnik S. N., Bukovsky M.E. Variability of the water regime in the Don basin rivers. Vestnik Voronezskogo gosudarstvennogo universiteta. Geografia geoekologia, 2020, No. 3, pp. 4048. (In Russ.) DOI: https://doi.org/10.17308/geo.2020.3/3022

\section{REFERENCES}

1. Bukovskii M.E., Chernova M.A. [The change in summer runoff of the rivers of the Don basin in the territory of the Tambov region over the past half century]. Trudi 9- $i$ Mejdunar. nauch.-prakt. konf. "Ekologiya rechnih basseinov" [Proc. of the 9th Int. Sci.-Pract. Conf. "Ecology of river basins"]. Vladimir, 2018, pp. 33-39. (In Russ.)

2. Vladimirov A. M. Faktori, opredelyayuschie vozniknovenie ekstremalnih rashodov i urovnei vody polovodya [Factors that determine the occurrence of extreme flow rates and flood water levels]. Uchenie zapiski RGGMU, 2009, no. 9, pp. 22-39. (In Russ.)

3. Dmitrieva V.A. Gidrologicheskiy rezhim rek donskogo basseyna [The hydrological regime of the Don basin rivers]. Vestnik Voronezskogo gosudarstvennogo univer-

\section{Чернова Мария Александровна}

аспирант Тамбовского государственного университета им. Г.Р. Державина, г. Тамбов, Российская Федерация, ORCID: https://orcid.org/0000-0002-3328-7437; e-mail: chernovamarusya@mail.ru

Дудник Сергей Николаевич

начальник Тамбовского центра по гидрометеорологии и мониторингу окружающей среды - филиала Федерального государственного бюджетного учреждения «Центрально-Черноземное управление по гидрометеорологии и мониторингу окружающей среды», г. Тамбов, Российская Федерация, ORCID:

https://orcid.org/0000-0003-2661-0854; e-mail: tgmc@mail.ru

Буковский Михаил Евгеньевич

канд. геогр. наук, доцент, Тамбовского государственного университета им. Г. Р. Державина, г. Тамбов, Российская Федерация, ORCID: https://orcid.org/0000-0002-2773-3816, e-mail: mikezzz@mail.ru siteta. Geografia geoekologia, 2018, no. 4, pp. 77-84. (In Russ.)

4. Dudnik N.I. Priroda Tambovskogo kraya (populyarnie geograficheskie ocherki) [Nature of the Tambov region (geographical population essays)]. Tambov, Tambov State University named after G. R. Derzhavin Publ., 2000. 156 p. (In Russ.)

5. Resursi poverhnostnih vod SSSR: Gidrologicheskaya izuchennost [Surface water resources of the USSR: Hydrological study]. V. 7. Donskoi raion. Leningrad, Gidrometeoizdat, 1973. 460 p. (In Russ.)

Conflict of interests: The authors declare no information of obvious and potential conflicts of interest related to the publication of this article.

Received: 04.03.2020

Accepted: 26.07.2020

\section{Maria A. Chernova}

Post-graduate student of the Tambov State University named after G. R. Derzhavin, Tambov, Russian Federation, ORCID: https://orcid.org/0000-0002-3328-7437, e-mail: chernovamarusya@mail.ru.

Sergey N. Dudnik

Head of Tambov center for hydrometeorology and environmental monitoring - a branch of the Federal state budgetary institution "Central Chernozem administration for hydrometeorology and environmental monitoring", Tambov, Russian Federation, ORCID: https://orcid.org/0000-0003-2661-0854, e-mail: tgmc@mail.ru

Mikhail E. Bukovsky

Cand. (Geogr.) Sci., Associate Professor, Tambov State University named after G. R. Derzhavin, Tambov, Russian Federation, ORCID: https://orcid.org/0000-0002-2773-3816, e-mail: mikezzz@mail.ru 